\title{
Review of American Nationalism and the Historical Development
}

\author{
Haoyang $\operatorname{Tian}^{1, *}$ \\ ${ }^{1}$ The High School Affiliated to Renmin University of China, Beijing, China \\ *Corresponding author email: guanghua.ren@gecacademy.cn
}

\begin{abstract}
This article outlines the history of American nationalism and analyzes the reasons for its recent increase. The paper describes the benefits and dangers of American nationalism for the United States and the world. It identifies the decreasing share of the American middle class and the increasing minority population as the reasons for the recent rise of American nationalism. This study is based on the research method of literature review. Data sources included books from John Fousek, which argue for the merging of American nationalism and American international intervention in the Cold War. This study also cites several Trump speeches to argue for Trump's nationalist tendencies and Trump's contribution to American nationalism. This study outlines the journey of American nationalism from its origins in opposition to British colonial rule to its legitimization of American expansion into the West and its merging with American international interventionism during the Cold War. It discusses the reasons for the recent extremes of American nationalism due to the shrinking American middle class and the growth of ethnic minorities. The recent rise of extreme nationalism around the world has exacerbated conflicts within and between many countries and has threatened world peace and the democracy of various countries. The significance of this study is to outline nationalism in the United States, explain the reasons for the rise of nationalism in the United States, and warn of the dangers of extreme nationalism in the United States and around the world.
\end{abstract}

Keywords: Nationalism, America, Manifest Destiny, Isolationism.

\section{INTRODUCTION}

In recent years, nationalist sentiment in the United States has become increasingly polarized and has had a greater impact on the United States politically, economically, socially, and diplomatically. Politically, the Trump administration has taken advantage of white nationalist sentiment and ignorance of racism to win the election, and its political initiatives after taking office have intensified ethnic conflicts. Economically, against the backdrop of industrial shifts and population movements due to economic globalization, the traditional U.S. manufacturing economy is sluggish, with fewer jobs and stagnant living standards for the middle class. Socially, there has been an increase in the number of extreme cases of racial hatred and attacks on police officers, and the "Black Lives Matter" movement is sweeping the country; diplomatically, U.S. nationalism places the highest priority on safeguarding national interests and national security, and is committed to changing the status of the United States in international organizations. The U.S. decision to withdraw from many international organizations, such as the Paris climate agreement, in recent years has also been widely seen as influenced by the rise of nationalism. We can see American nationalism is changing the traditional American foreign policy more and more.

For example, Albert Weinberg's book Manifest Destiny: A Study of National Expansionism in American History considers the concept of "Manifest Destiny" as the ideological foundation of American national expansionism; Lawrence Kaplan's Nationalism analyzes the connotation of American nationalism and the concept of American national identity. Lawrence Kaplan's Nationalism analyzes the connotation of American nationalism and the process of American national identity and discusses the typical manifestations of American nationalism. Minxin Pei's paradox of American Nationalism points out that there is a double standard in the use of nationalism in the United States; Samuel Huntington's Strong Nationalism clearly states that only nationalism can defend the established system and national interests the United States. 
Based on previous studies, this paper will explore the influence of American nationalism on U.S. foreign policy in the light of the new phenomena and problems that have emerged in contemporary American society, the origin and development of American nationalism. This study will also attempt to examine, through American nationalism, why nationalism emerged and how it has affected modern international relations. We hope this study will alert people about the damage that extreme nationalism can do to the country and the world and show people how to stop extreme nationalism from arising.

To better present the content of the study, this paper is divided into four parts to develop the argument. Firstly, the paper traces the emergence of American nationalism in history from when it arose. Secondly, the paper will review the changes of American nationalism from its birth to the two world wars to the Cold War and its impact on American diplomacy. Thirdly, it describes the development of American nationalism in recent years and its role in the assassination of Sulaimani and other events. Fourthly, it will conclude with a summary of American nationalism and its influence and expand to nationalism and its impact on modern international interactions to conclude.

\section{HISTORY AND DEVELOPMENT}

\subsection{The Birth of American Nationalism}

Before the War of Independence, the colonial people of North America had no unified identity. The original settlers and their original descendants still considered themselves British to distinguish themselves from the French, Spanish, and Germans who came to the Americas. This British identity faded over time, and the fading memory of its native land and a new state-based identity gradually became mainstream. The outbreak of the War of Independence on April 19, 1775, made possible the union of the people of the North American states, who faced a common enemy. Here, Paine pioneered the use of the nation to refer all the people of North America. The Declaration of Independence's publication on 4 July 1776 declared that the Americans had become "one people" and that the British were "another" people. The Declaration also claims that existence, freedom, and pursuit of happiness are gifted human rights. The government is established to guarantee these rights; the power comes from the consent of the governed, which can be changed or abolished if the government damages the original intention. All this shows that the people of the various colonies of North America had united into a nation based on basic liberal principles and were determined to fight to realize these principles. After seven years of arduous war, Britain lost in 1783 and was forced to sign a Treaty of Paris to recognize American independence.

\subsection{Westward Movement, Manifest Destiny, and expansion of the U.S.}

From third President Jefferson, the United States began expanding from the east coast to the west coast. The initial expansion was the purchase of the French Louisiana colony. This act initially had little ideological consideration, purely for economic gain. Jefferson himself feared that land purchases would cause the central government to threaten the American local rule and Republican tradition before his final decision. Several subsequent U. S. governments continued to support the westward expansion, and the resulting continental expansion fever culminated in the 1840s. As American immigrants moved further into the west, conflict with local Native Indians intensified, and the main ways of expansion shifted from buying land purchases to direct aggression lacking legitimacy. In this context, "destiny" comes. The so-called "destiny" represents a quite common and popular belief that American culture, religion, morality, and politics are unique and the most superior. American immigrants should carry this civilization to the "wild" west coast, and the Indians who stop the civilization spread should be expelled. To some Americans, this expansion is not only necessary but unstoppable, the natural statutory rule. Obviously, as a core element of American nationalism, the concept of "manifest destiny" is in the line that Americans have consistently self-identified as the voter of God.

Until the end of the 19th century, "expansion dominated American life for nearly three centuries. The expansion movement was coming to an end as immigration to the Pacific coast and the occupied free lands. If this capacity of expansion no longer works, it is a reckless prophecy. The call for strong foreign policy, canals between the two oceans, and the extension of American forces to native islands and neighboring countries-all shows that the movement will continue." This is true that, in addition to continuing established policies in the Western Hemisphere, its expansion momentum has begun to turn to the world beyond the ocean. Since then, the US expansion has entered a new and important period in history [1].

The westward movement created the national character and national spirit of the United States. At the end of the 19th century, the "frontier" tradition has gradually condensed into the eternal "American spirit", and the concept of "western" has become a spiritual pillar for Americans to undertake their nation mission [2].

At the turn of the 20th century, after the SpanishAmerican War, the American people have surrendered to the temptation of expansionary nationalist foreign policy. Still, many Americans finally selected the United States to lead the world's regeneration. Namely, the growing American strength must be used to fight the world's evil 
and act as the power to promote civilization. This nationalist thought legitimized the American war against Mexico, Spain, and colonizing the Philippines and expanding to the west.

\subsection{World War I and World War II}

During World War I, foreign interference and expansion stagnated before World War. Unfamiliarity with the Old World and fear of modern warfare made isolationism an embodiment of nationalism the dominant thought of American diplomacy during this period. The United States has almost completely abandoned its intervention in Europe and the rest of the world.

With the outbreak of World War I and the spread of the United States, isolationism within the United States was temporarily replaced by internationalism. Some interventionists, such as Woodrow Wilson, attempted to recreate the international order by American standards after the war and spread American liberal values to Europe. These did not become a reality after the war victory, which voluntarily withdrew from the League of Nations and abandoned the transformation of the existing international order. Interventionism has suffered major setbacks.

After the First World War, although the return of isolationism withdrew the US from the League of Nations, the interventionist influence did not give up to rejoin international politics. As Woodrow Wilson mentioned in a speech in 1919, "The hearts of the American people are pure. The hearts of its people are faithful. They are the great idealistic forces in history ... I believe that the American people have spiritual energy that no other nation can contribute to human freedom." America has special qualities to achieve its destiny and save the world [3].

Isolationist trends regained dominance in American politics between World War I and World War II. After withdrawing from the League of Nations, American interference and involvement in international affairs in the Old World have always remained low. However, with the Japanese invasion of China and the outbreak of World War II, isolationism was forced to give way to interventionism under the impact of reality. As Japan's expansion ambitions gradually demonstrated, the United States imposed multiple strategic embargoes on Japan, including vital oil. This also forced the Japanese to sneak attacks on Pearl Harbor. United States' entry into war marks the final collapse of isolationism. In the war, the United States clearly realized that it would play an important role in the future international order and planned the sphere of influence in Europe with the Soviet Union. After the American forces recovered Nazioccupied Western Europe, the Western European states entered the American sphere of influence. Mass US intervention in Europe and world affairs began.

\subsection{Cold War period}

After World War II, isolationism was completely abandoned by the mainstream political forces in the United States and lacked support among the people. Internationalism and foreign interference have become the benchmark for US foreign policy. This time, they want to create a world order that can enhance American interests to enhance its wealth and power and push its values to any corner of the world [4]. Indeed, from Harry Truman's 1947 claim that "the rapid development gives us great responsibility" to the Eisenhower administration seeing the need to liberate the enslaved people of Eastern Europe, Kennedy declaring to the world "any price, and burden" to ensure victory, and "the Clinton administration's free society expanding democracy and market economy," demonstrating the fundamental coherence of American foreign policy over the past century and a half.

The rise of internationalism, however, does not represent the decline of nationalism. In the liberal international order supported by internationalism, the United States occupies a dominant position due to its economic size and military forces. At the same time, nationalists were satisfied with this leadership and used this position to spread American culture worldwide and seek economic benefits for the United States. President Truman said that American nationalism developed to a new stage, called "nationalist globalism", in which the nation's national self-interests were equal to global altruism. Since the two were so indistinguishable, postwar American nationalism was two sides of the same coin as post-war American globalism [5].

\section{STATUS AND CHANGE OF AMERICAN NATIONALISM}

\subsection{Current status}

The United States, from the Korean War, the Vietnam War, the Gulf War, and the Kosovo War to the war in Afghanistan, especially the Iraq War, was deeply influenced by national nationalism.

In the late 20th century, due to the continuous increase of Mexican and Latin American immigrants, the growth of various minorities, and threats to mainstream culture, the American national identity and national identity faced challenges.

The Nativism movement in the United States often carries the white supremacy of racism. Historical participants of Nativism movements such as the KKKK and the Tea Party were mostly white. In the 2016 election, 90 percent of his supporters were white, especially white college-less degrees opposed to free trade and immigration, who overwhelmingly supported Trump. His anti-politically correct remarks brought the previously 
repressed non-mainstream right into the mainstream political landscape.

Trump declared that "the nation-state remains the true foundation of happiness and harmony" and explicitly regards "America First" as its creed [6]. Trump said in his speech that every trade, tax, immigration, and diplomatic decision would take the well-being of U. S. labor and American families [7]. All countries have the right to place their interests first. The in-depth development of globalization has stimulated the optimism of many people, who think that both national sovereignty and national sentiment will gradually weaken, and their identity will move from the nation-state to the subnational or global level. But the reality is far from this. Trump's American First principle, Brexit, and the rise of far-right forces in Europe all prove that the depth of globalization will stimulate nationalist sentiment.

Trump's election was inseparable from his racist remarks and his series of actions after taking power, even more stimulated and indulged in the frenzy of white nationalism in the United States. Matthew Contenetti once noted, "Trump is just the appearance of the problem. There is a stronger force behind him. We should find clear is not Trump doctrine, but the concept behind it, that is nationalism [8]."

On January 25, 2017, Trump signed a presidential executive order ordering about 2,000 miles of isolation walls along the U. S. -Mexico border. Mexican President Pena was in crisis when he announced the cancellation of the US-scheduled visit on January 31 . However, there is never a high wall in the world that can never be crossed. The long borderline between America and Mexico is destined to be broken through by the border violators due to the lack of monitoring. Objectively speaking, "building high walls" cannot completely block the border Drug smuggling and other criminal activities will be rampant, and the domestic security problem in the United States will not be solved because of the wall [9].

\subsection{Reason}

According to the National Bureau of Statistics, in $1965,11 \%$ of the white population, $11 \%$ black, $4 \%$ Hispanic, and $1 \%$ Asian. Since then, the black percentage has remained stable, but by 2020 , Hispanic speakers were $18 \%$ of the population, $6 \%$ Asian, while whites declined to $62 \%$. By 2060 , non-white population growth will come predominantly from Latino, rising from $17.4 \%$ in 2015 to 28.6\%, and African and Asian Americans will continue to grow, while the proportion of white groups (non-Latino) will drop to $40 \%$. In addition, the National Bureau of Statistics expects fundamental changes in its demographic structure by 2044 , with the white population no longer having a majority in American society [10].
Immigration could hit the domestic labor market, increase competition, lower wages, and lead to unemployment. Studies have shown that immigration will have a certain negative impact on the wages of loweducated local employers, reducing them by about $4.7 \%$ [11].

Immigration may trigger the psychological imbalance of residents, produce a relative sense of deprivation, and then stimulate naturalism and racial discrimination. Antiimmigration Americans are particularly disgusted with their welfare resources who see them as queue-jumping and lazy, receiving social treatment at the expense of bottom white people, and see Democrats as a boost to the issue [12].

Immigration can lead to excessive social diversification and trigger a national identity crisis. Samuel Huntington, who warned in Who We Are, said its national identity has been threatened by massive Hispanic immigration and said the potential to divide into "two peoples, two cultures and two languages."

In 2013, George Zimmerman, a police officer who shot black youth, was acquitted, and the triggered Black Lives Matter campaign swept across the United States, intensifying the split between groups.

Trump supporters can be divided into two categories: the traditional Republican voters and the silent and former Democratic voters attracted by Trump. White blue-collar and rural whites supported Trump because they suffered severe economic difficulties and cultural anxiety. The main economic difficulties it faced are stagnant income and unemployment. For the last halfcentury, the middle and white blue-collar classes have shrunk in the US.

The proportion of middle-class Americans has decreased to $49.9 \%$ from $61 \%$ in 1971 to 2015 , while low-income earners rose from $25 \%$ in 1971 to $29 \%$ in 2015. In the last 20 decades, the actual income of most Americans has largely stagnated. The median US household income in 2014 was $\$ 53,657$, equivalent to $\$ 53,290$ in 1989 [13]

\section{INFLUENCE AND FUTURE OUTLOOK OF AMERICAN NATIONALISM}

\subsection{American Exit from International Organizations}

On October 13, 1999, the United States Senate voted against the Comprehensive Nuclear-Test-Ban Treaty resolution of 51 to 48 . The national nationalism of the United States maintains its national interests as the highest criterion and has completely ignored the common interests of the international community, which is an act of extreme self-interest and a typical kind of extreme nationalism. 
In the banner of giving priority and white supremacy in the United States, the Trump administration ignores international responsibility and destroys international cooperation. There are countless examples of "group withdrawal" and "contract destruction", but in fact, to please the white community. Taking the withdrawal of the Trans-Pacific Partnership (Trans-Pacific Partnership Agreement) is that Trump wants to please his voters by showing tough, and as he said, quitting TPP is a "big good thing" for American workers. Under the influence of the wave of globalization, the world economy has developed rapidly, fighting US manufacturing because the agreement advocates further removing trade barriers between the Member States and advocates freedom of service and the market. This leads to cheap labor and goods from underdeveloped countries like Vietnam, Malacia, Mexico, and Chile entering the US market, which will further squeeze the living space of American businesses and workers, with white blue-collar groups bearing the brunt. On this judgment, Trump raised the banner against TPP and won the majority of white workers.

\subsection{US Foreign Intervention Action}

With the help of the superiority of domestic nationalism to American politics, American foreign policy promotes its hegemony policy outward and seeks to maximize its interests in the world. It was argued that nationalism had become an increasingly important driving force in implementing and implementing contemporary American foreign policy. Such as the National Security Strategy report issued on September 17 2001, Bush Administration declared that the United States has the right to act at any time or anywhere in any country that the United States sees as a threat to American interests or may become a threat in the future [14]. With the position of the only superpower, the United States adopts unilateralism. It vigorously promotes American values, which self-scale nationalism has become one of the triggers to destroy harmony in the world.

The expansion of the extension of domestic democracy brought about by social diversification has made the values of the United States have broader social adaptability, and they have evolved into a special form of American nationalism in foreign affairs, resulting in the expansion of hegemonic thought. The experience of domestic social development makes the United States have little moral scruples when being in the pursuit of selfish national interests, full of self-righteous leadership desire, and act as the "savior" of the world. However, to the objective extent, under the restriction of some regulations of international organizations and order and the norms of international relations, as an important pole in the world, this superpower has a certain horizontal role in the international pattern. It plays an irreplaceable leading role in handling international affairs to a certain extent. At the same time, in the American checksbalances, decision-making mechanisms, social structure, and cultural traditions, there are still some self-restraint and self-reflection factors, which also set a boundary for American hegemonism to fanatical. From this point of view, ecumenical nationalism in America has a certain positive role. We should recognize that the strength and leadership of America are indispensable to the peace and prosperity of the world.

\subsection{The Future Situation of Nationalism}

The populist and white race-nationalist risks American politics. It can be predicted that the proportion of the white American population will decline, and many white economic and social statuses will continue to deteriorate, which may be difficult to ease in the short period of anger over minorities and immigrants.

According to the 2020 survey, the foreign-born population reached a record 44.8 million in 2018. The number of immigrants living in the United States has more than tripled since the US immigration law replaced the national quota system in 1965. Today, immigrants account for $13.7 \%$ of the U. S. population, almost three times that in $1970(4.8 \%)$. In 2018, the proportion of immigrant women who delivered $(7.5 \%)$ was already higher than Native American women (5.7\%). If the current immigration trend continues, immigrants and their descendants are expected to represent $88 \%$ of the US population growth by 2065 [15].

An August 2019 report by McKinsey noted that the US GDP could gradually increase by $6 \%$ if the income gap was offset by systemic racism by 2028 . It can be seen that although racism will bring a short return to the white group on the surface, it will have a negative impact on the economic health and balance of the whole society in the long run [16].

Today, the demographic structure of the United States is changing significantly, the rapid growth of the American minority population represented by Hispanics, the declining proportion of white people, Latino in the southern US Hispanic, the white identity crisis, and the challenge of American nationality is becoming a reality. As a result, domestic multiculturalism will be challenged when Trump instigated white nationalism [17].

From their faith and interests, many white people feel "minority" anxiety. Republicans are active in dog-whistle politics, neither irritating centrist voters and quietly pleasing target groups, throwing seemingly harmless tax cuts, welfare reform, law, and order, provoking audience stereotypes about the black community, prompting them to vote. To "defend white property and security [18]."

Rising white nationalist nationalism led to a growing threat of factional violence in support of bloodshed and advocating racial war, threatening American security and 
world peace. The annual report by the Southern Poverty Law Center on extremist groups has increased the number of white nationalist organizations worldwide by $55 \%$ over the past three years, from 100 in 2017 to 148 in 2018 to 155 in 2019. For the predominantly white West, the core thought of white American nationalism coincides with the claims of western white supremacist groups. When white American nationalism developed in full swing, it aroused a huge social response, instigating white nationalists in western countries to plan action. For example, in December 2019, British police arrested a Polish right-wing extremist, Philip Bednarchk, for carrying bomb-making materials. Police found that he also held a manifesto from a white extremist group that created the shooting in Christchurch, New Zealand. In May 2020, Bednarchk pleaded guilty to terrorism and stated that he was mostly targeted by Muslims, Jews, and others due to dissatisfaction with the increasingly "substituted" white people's status. Thus, the development of white supremacism has gradually threatened the western countries outside the United States. The extreme tendency of white nationalism led by the United States has worsened the living situation of Muslims, Jews, and other nationalities globally. It has also caused terrorism to take advantage of the act of terrorism under the banner of violence and violence. The situation of the fight against terrorism is becoming increasingly severe. However, the emergence of the "US First" thinking has prompted the United States to continuously reduce its investment in anti-terrorism, transfer, and evade international responsibilities, adding new obstacles and difficulties for anti-terrorism in the future $[19,20]$.

\section{CONCLUSION}

American nationalism has played an important role in the history of the United States. We can see the influence of nationalist ideas in many important events from the United States' founding to the present. In special periods such as the Cold War, when the national interests of the United States were unprecedentedly aligned with those of the world, American nationalism played a useful role in promoting democratization and economic development in the world. However, American nationalism has also posed a lot of damage to the United States and the world in its development. "America First" is the slogan of today's American nationalism and the embodiment of the view that national interests are paramount in American nationalism. This ideology was put into practice by the isolationist policies of the two world wars, the intervention in Central America in the early 20th century, and the military intervention in the oil-producing countries of the Middle East after the Cold War. However, this ideology of serving exclusively national interests does not necessarily bring the greatest benefit to the country, just as these events above did not bring benefit to the United States either. Isolationism did not prevent a world war from reaching the United States, but rather the United States suffered additional casualties because of its lack of preparation for the war and its late entry into the war. The war in the Middle East cost the United States one trillion dollars, which is more than the combined budget of the United States for thirty years. And the war did not give the U.S. economic benefits sufficient to offset the losses, nor did the dollars promote democratization in the Middle East. For the worst part, it allowed terrorist groups to rise into the chaos. We should note from this that nationalism is not conducive to the long-term interests of the nation's people and also undermines the legitimate rights of other peoples. This is one notable reason why nationalism should be cautioned against and rejected.

Nationalism does not arise naturally, and the reasons behind it deserve our attention, considering the harm it causes. The U.S. middle class, especially workers, has suffered in the process of economic globalization, which is an important reason for the extremes of nationalism in the United States. Suppose the U.S. and other developed countries want to avoid further extremes of nationalism that bring losses to society and the world. In that case, they should use various ways to raise the living standards of this group of people and ensure that the living standards of workers do not decline any further. Another source of nationalism in the United States is racial tension, which is particularly evident in an ethnically diverse country like the United States and reflected in other countries. The U.S. and countries facing similar problems should actively pass legislation to discourage hate cases and discrimination and use education to promote mutual understanding and communication between ethnic groups and weaken ethnic identity in non-essential situations to achieve a reduction in ethnic conflicts.

\section{REFERENCES}

[1] He Shunguo. General American History [M]. Shanghai: Xuelin Press, 2001.

[2] Cao Ruichen. Nationalism in the Process of Modernization - The Historical Tracks of American Nationalism [M]. World Nation, 2004, (3).

[3] Arthur M. Schlesinger,Jr. The Cycles of American History,Boston: Houghton Mifflin Company,1986.

[4] Warren I. Cohen.The Cambridge History of American Foreign Relations [M]. Xinhua Publishing House, 2004.

[5] John Fousek. To Lead the Free World: American Nationalism and the Cultural Roots of theCold War,Chapel Hill and London: The University North Carolina Press,2000. 
[6] Donald J. Trump Foreign Policy Speech,"April,27,2016,https://www.donaldjtrump. com/press-releases/donald-j.-trump-foreign-policyspeech.

[7] Aaron Blake, "Donald Trump's Full Inauguration Speech Transcript,Annotated," The Washington Post,January 20,2017.

[8] Matthew Continetti. How conservatism is changing in the Trump era. [EB/OL]. [2020-09-15]. https://www.nationalreview.com/2017/02/nationali sm-conservatism-republican-party-american-rightdonald-trump/

[9] John Sides,Michael Tesler,and Lynn Vavreck. The Electoral Landscape of 2016. The Annals of the American Academy of Political and Social Science,2016. pp.: 58.

[10] SandraL. Colby and Jennifer M. Ortman. Projections of the Size and Composition of the U.S. Population:2014-2060. [EB/OL]. [2020-09-15].

[11] George J. Borjas and Lawrence F. Katz, "The Evolution of the Mexican-Born Workforce in the United States," in George J. Borjas, ed., Mexican Immigration to the United States, University of Chicago Press, 2007, pp. $13 \sim 15$.

[12] Arlie Russell Hochschild,Strangers in Their Own Land: Anger and Mourning on the American Right,New York: The New Press,2016,pp. 137 139.

[13] U. S. Census Bureau, "Income and Poverty in the United States,2014," pp. 31 33, https: / /www. census.gov/content/dam/Census/library/publication s/2015/demo/p60-252. pdf

[14] Cao Ruichen. Nationalism in the process of modernization [J]. World Nations, 2004, (3): 14-22

[15] Abby Budiman. Keyfindings about U.S. immigrants. [EB/OL]. [2020-09-15].

[16] Nick Noel,Duwain Pinder,Shelley Stewart,Jason Wright. Theeconomic impact of closing the racial wealth gap [EB/OL]. [2020-1013].https://www.mckinsey.com/industries/publicand-social-sector/our-insights/the-economicimpact-of-closing-the-racial-wealth-gap.

[17] Samuel Huntington. Who is an American? American national character challenges. Beijing: Xinhua Publishing House, 2010: pages 161-187.

[18] Year in Hate and Extremism. Montgomery:Southern Poverty Law Center,2020.

[19] Daniel Koehler. Violence and Terrorism from the Far-Right: Policy Options to Counter an Elusive
Threat. The Hague: International Centrefor Counter-Terrorism Policy Brief, 2019. Page: 2

[20] Liu Zhenye and Chen Qiu. Turning in the US counterterrorism strategy. Modern International Relations, 2020 (2): p. 11. 